\title{
A szakmai élet minőségét mérő kérdőív (Professional Quality of Life Scale) magyar változatának validálása
}

\author{
Kegye Adrienne dr. ${ }^{1}$ - Takács Szabolcs dr. ${ }^{2}$ - Ries Borbála ${ }^{3}$ \\ Zana Ágnes dr. ${ }^{1}$ - Hegedús Katalin dr. ${ }^{1}$

\begin{abstract}
${ }^{1}$ Semmelweis Egyetem, Általános Orvostudományi Kar, Magatartástudományi Intézet, Budapest Budapest
\end{abstract} \\ ${ }^{2}$ Károli Gáspár Református Egyetem, Pszichológiai Intézet, Általános Lélektani és Módszertani Tanszék, \\ ${ }^{3}$ Eötvös Loránd Tudományegyetem, Pedagógiai és Pszichológiai Kar, Budapest
}

\begin{abstract}
Bevezetés: A szakmai élet minőségét mérő (ProQOL) skálát a rendkívül stresszes eseményeken átesett emberekkel végzett munka pozitív és negatív hatásainak mérésére fejlesztették ki. A szenvedéssel, halállal, haldoklással, a másik ember traumájával való mindennapi találkozás fizikálisan és emocionálisan is befolyásolhatja a palliatív-hospice teamekben dolgozók életminőségét.

Célkitüzés: A vizsgálat célja a ProQOL5 kérdőív magyar változata pszichometriai tulajdonságainak és faktorszerkezetének felmérése volt, ami lehetővé teszi az együttérzésből eredő kifáradás és elégedettség, a másodlagos traumatizáció és a kiégés mérését. Hosszú távú cél a hospice-dolgozók számára képzési és intervenciós módszerek kidolgozása, elégedettségük, fizikai és lelki jóllétük növelése, pályán maradásuk elősegítése.

Módszer: A keresztmetszeti, kérdőíves felmérésbe hospice-dolgozókat vontunk be. A kérdőíveket anonim, nyomtatott formában tettük elérhetővé. A validáláshoz a Rövidített Maastricht Vitális Kimerültség Kérdőív, a Rövidített Beck Depresszió Kérdőív, a CES-D Depresszió Szưrő Kérdőív és a WHO Jóllét Kérdőív rövidített (WBI-5) magyar nyelvü változatait használtuk fel.

Statisztikai analizis: Az elemzésekhez IBM SPSS 23.0@ programcsomagot használtunk. A mérőeszköz faktorstruktúrájának feltárásához exploratív faktoranalízist (fókomponens-elemzés, Varimax rotáció) végeztünk, majd elkészítettük azt a 4 skálát, amely megfelelő Cronbach-alfa-értékekkel rendelkezett a további vizsgálatokhoz.

Eredmények: Értékelhető kérdőíveket 188 fötől kaptunk vissza (nő 86,2\%, férfi 13,8\%). Többségük nővérként és az otthoni hospice-ellátásban dolgozik (94 fö). A megalkotott 4 skála belső konzisztenciája a Cronbach-alfa-értékek alapján elfogadható minőségű. A kiégést mérő kérdések belső konzisztenciája alacsony. Mérőeszközünk skáláinak együttjárása a külső validitást mérő, standardizált skálákkal megfelelő erősségú és irányú.

Következtetések: Kérdőívünk a belső és a külső mutatók alapján megfelelő konzisztencia mellett, az elvárt értékek szerint méri az általunk vizsgálni kívánt jelenségeket.

Orv Hetil. 2018; 159(35): 1441-1449.
\end{abstract}

Kulcsszavak: ProQOL, a szakmai élet minőségét mérő kérdőív, validálás, hospice, palliatív ellátás

\section{Validation of the Hungarian version of the Professional Quality of Life Scale}

Introduction: The Professional Quality of Life Scale, measuring the quality of professional life, has been developed to examine the positive and negative changes in the work of those who have undergone extremely stressful experiences. The quality of life of the personnel of palliative-hospice teams may be influenced physically as well as emotionally by their every-day experiences of suffering, death, dying and the patients' traumas.

Aim: The aim of the study was the examination of the psychometric features and factor structure of the Hungarian version of the Professional Quality of Life Scale questionnaire, which can measure compassion fatigue and satisfaction, secondary traumatisation and burnout. Our long-term objective is the development of formative and intervention strategies for hospice workers in order to increase their satisfaction, physical and mental well-being and their willingness to work in hospice.

Method: The cross-sectional, questionnaire study was made with hospice workers. The questionnaires were available in an anonym, printed form. We used the Hungarian versions of the Shortened Maastricht Vital Exhaustion Questionnaire and of the Shortened Beck Depression Scale, of the CES-D Depression Scale and of the Shortened WHO General Well-Being Scale to validate. 
Statistical analysis: IBM SPSS 23.0(C) software was used for the analysis. To explore the factor structure of the measurement scale, explorative factor analysis was made (analysis of the main component, Varimax rotation); subsequently, 4 scales were prepared the Cronbach-alpha values of which were suitable for further examination.

Results: 188 questionnaires were sent back (female 86.2\%, male 13.8\%); the majority work as nurses and in home hospice care (94 people). The inner consistency of the created 4 scales is acceptable according to the Cronbach-alpha values. The inner consistency of the questions regarding burnout is low. The correlation of our measurement scales with the standardised scales for outer validity has sufficient strength and direction.

Conclusions: Our questionnaire can measure the phenomena under examination according to the expected values, with suitable consistency on the basis of the inner and outer indicators.

Keywords: ProQOL, professional quality of life, validity hospice care, palliative care

Kegye A, Takács Sz, Ries B, Zana Á, Hegedús K. [Validation of the Hungarian version of the Professional Quality of Life Scale]. Orv Hetil. 2018; 159(35): 1441-1449.

(Beérkezett: 2018. március 15.; elfogadva: 2018. május 9.)

\begin{abstract}
Rövidítések
BDI $=($ Beck Depression Inventory $)$ Rövidített Beck Depreszszió Kérdőív; CES-D = $($ Center for Epidemiologic Studies Depression Scale) CES-D Depresszió Szürő Kérdőív; CF = (compassion fatigue) együttérzésbőll eredő kifáradás; $\mathrm{CS}=$ (compassion satisfaction) együttérzésből eredő elégedettség; KMO = Kaiser-Meyer-Olkin-érték; ProQOL = (Professional Quality of Life Scale) a szakmai élet minőségét mérő skála; SD = (standard deviation) szórás; TUKEB = Tudományos és Kutatásetikai Bizottság; VKK = Rövidített Maastricht Vitális Kimerültség Kérdőív; WHO = (Word Health Organization $)$ Egészségügyi Világszervezet; WHO WBI-5 = (WHO Well-Being Index-5) WHO Jóllét Kérdőív rövidített (WBI-5) magyar változata
\end{abstract}

Az életvégi ellátásban általában interdiszciplináris teamek dolgoznak, amelyek tagjai különböző mértékben vannak kitéve az emberi szenvedés, fájdalom, haldoklás látványának. A hospice-munka a világ minden táján egyike a mind fizikálisan, mind lelkileg legmegterhelőbb hivatásoknak [1]. Korábbi felméréseink szerint az ellátásban részt vevő́k fáradtak, krónikus fájdalmaik vannak, alvászavarral küszködnek, mégis szívesen végzik ezt a munkát, és hosszú távon - „évtizedekig”, „amíg csak lehet” - szeretnék azt folytatni [2]. Ezen paradoxon hátterében a szakmai életminőség - a segítő munkával kapcsolatos érzés minősége - vizsgálatának nagy a jelentősége. A szenvedő emberekkel és családtagjaikkal végzett segítő munkának lehetnek pozitív vagy negatív hatásai, ezeket az együttérzésből eredő elégedettség (CS) mint a „gondoskodás jutalma" vagy az együttérzésból eredő kifáradás $(\mathrm{CF})$ mint „a gondoskodás ára” fogalmaival írták le [1, 3-5].

A szakmai élet minőségét mérő skálát (Professional Quality of Life Scale - ProQOL) a rendkívül stresszes eseményeken átesett emberekkel végzett munka pozitív és negatív hatásainak mérésére fejlesztették ki. Ezen paraméterek vizsgálatában - az alkalmazási útmutató szerint - ez a leggyakrabban használt mérómódszer, mely a segítő foglalkozások számos területén alkalmazható, például egészségügyi szakemberek, szociális munkások, tanárok, ügyvédek, rendőrök, tûzoltók, papok, közlekedésben dolgozók, katasztrófaelhárítók és mások esetében [6].

Az emberi szenvedésnek, halálnak, haldoklásnak, a másik ember traumájának való mindennapi, rendszeres kitettség befolyásolhatja a palliatív-hospice teamekben dolgozók szakmai életminőségét. A szakmai élet minőségét mérô skálát a közelmúltban egyre gyakrabban alkalmazták a palliatív-hospice ellátásban dolgozóknál a pozitív és negatív aspektusok felmérésére $[1,7,8]$.

\section{Célkitüzés}

A vizsgálat célja a ProQOL5 kérdő́ív magyar változata pszichometriai tulajdonságainak és faktorszerkezetének felmérése volt. A kérdő́iv magyar nyelvű változatának kialakítása lehetővé teszi a súlyos állapotú, haldokló betegekkel foglalkozók körében a szakmai élet minőségének rendszeres utánkövetését, a súlyos állapotú betegekkel végzett munkából eredő előnyök és hátrányok feltérképezését. Ez pedig támpontokat adhat a hospice-szervezetek és a dolgozók számára képzési és intervenciós módszerek kidolgozására [9], melyekkel megelőzhetik az együtttérzésből eredő kifáradást, a kiégést, növelhetik a dolgozók elégedettségét, fizikai és lelki jóllétét. A vizsgálat hosszú távú célja, hogy mindezekkel elősegítsék a munkatársak pályán maradását [10].

\section{Módszer}

\section{Az eredeti méróeszköz bemutatása}

A teszt neve eredetileg Együttérzésből Eredő Fáradtság Önteszt (Compassion Fatigue Self Test) volt, amelyet Charles Figley az 1980-as évek végén fejlesztett ki. Stamm és Figley 1988-ban kezdődött együttmúködése során Stamm 1993-ban hozzátette az együttérzésből 
eredő elégedettség fogalmát, ezáltal a teszt neve Együttérzésből Eredő Elégedettség és Fáradtság Öntesztre (Compassion Satisfaction and Fatigue Test) változott. A folyamatos fejlesztés eredményeképpen jött létre az 1990-es évek végére a Professional Quality of Life Scale [6], amely folyamatos fejlesztés alatt áll. Jelenleg az ötös változatot használják (ProQOL5 English). A négyes és/ vagy az ötös verziót eddig 22 nyelvre fordították le.

A mérőeszköz 30 tételből áll (lásd Melléklet). Három alskálája - az együttérzésből eredő elégedettség, a kiégés és a másodlagos traumatizáció - 10-10 tételt tartalmaz. A válaszadók minden tételnél az előző 30 napban tapasztalt gyakoriságot jelölik egy ötfokú, Likert-típusú skálán a soha (1) és a nagyon gyakran (5) végpontok között. Az alskálák értékelésekor a magasabb pontszám súlyosabb állapotot jelez. A publikálási adatok alátámasztják a mérőeszköz belső megbízhatóságát (Cronbach-alfa) az alskálák esetében: az együttérzésből eredő elégedettség skála 0,88 , a kiégés skála 0,75 és a másodlagos traumatizáció 0,81. A mérések jó keresztvaliditást mutatnak, ami arra utal, hogy az alskálák valóban jól elkülönülnek egymástól [6].

Az eredeti kérdőívben a három alskálát úgy alakították ki, hogy az együttérzésből eredő elégedettséget, a másodlagos traumatizációt mérő tételek külön alskálát képeznek, míg a kiégésre és az együttérzésből eredő fáradtságra vonatkozó tételeket a kiégés alskála foglalja magában:

1. Együttérzésból eredő elégedettség alskála: azt mutatja, hogy az embert öröm tölti el, ha képes a munkáját jól végezni, és másoknak segítséget nyújthat munkája során. Jó érzésekkel viseltetik kollégái iránt, és elégedett azzal, hogy hozzájárul a megfelelő munkakörülmények megteremtéséhez, és tevékenysége társadalmilag is hasznos. Magasabb pontszáma a segítő szakmában való hatékony múködésre utal.

2. Kiégés alskála: a kiégés a gondoskodás negatív hatásainak egyik eleme, melyhez a reménytelenség érzése, a munkavégzés nehézsége és alacsony hatékonysága társul. Szoros összefüggést mutat az együttérzésben való kifáradással (CF). A negatív érzések fokozatosan alakulnak ki, és azt tükrözik, hogy az erőfeszítés hiábavaló és eredménytelen, melyet tetézhet a magas munkaterhelés, illetve egy nem megfelelően támogató munkahelyi környezet. A skálán elért magasabb pontszám a kiégés magasabb kockázatát mutatja. Ez az alskála 5 fordított tételt tartalmaz: 1, 4, 15, 17, 29.

3. Másodlagos traumatizáció alskála: az együttérzésben való kifáradás $(\mathrm{CF})$ másik komponense. A másodlagos traumatizáció - a más emberek traumás élményeihez kapcsolódó szekunder tapasztalat - általában gyorsan alakul ki, és egy bizonyos eseményhez kapcsolódik. Tünetei lehetnek a félelem, alvászavarok, tolakodó képek, valamint minden, az adott eseményre emlékeztető elkerülése. A magasabb pontszám esetén érdemes megvizsgálni a munka és a munkakörnyezet által keltett érzése- ket, különös tekintettel az ellátottak traumatikus élményeivel összefüggő, aggódást, ijedtséget kiváltókra.

Az alskálákon az átlagos pontszám 50 (SD 10). A válaszadók körülbelül 25\%-a 57 fölötti pontszámot, mintegy $25 \%$-a pedig 43 alatti pontszámot ér el [6].

\section{Vizsgálati minta}

A keresztmetszeti, kérdőíves felmérésbe a magyarországi hospice-ellátásban dolgozókat - orvosokat, nővéreket, egyéb területen dolgozó szakdolgozókat, mint például gyógytornász, dietetikus, szociális munkás - vontuk be. Fizetett dolgozók és önkéntesek is részt vehettek a vizsgálatban. A kérdő́iveket kizárólag nyomtatott formában, kongresszuson, tudományos ülésen és személyes egyeztetés után a szolgálatokhoz postai úton eljuttatva is elérhetővé tettük. A kutatás etikai engedélyének száma: 274/2013 (TUKEB).

\section{A validáláshoz felhasznált méróeszközök}

A szociodemográfiai adatok a válaszadók nemére, életkorára, legmagasabb iskolai végzettségére, a hospice-ban betöltött munkakörre és a munkavégzés ellátási formájára vonatkoztak.

A Röviditett Maastricht Vitális Kimerültség Kérdöín (VKK) magyar változata. Az öttételes, dichotóm skálájú (válaszlehetőségek: igen, nem) kérdőív a vitális kimerültségnek a fáradtságból, az energiahiányból és a fokozott irritabilitásból összeálló komplex élményét méri. A nagyobb pontszám a vitális kimerültség nagyobb mértékét jelzi. A skála belső megbízhatósága reprezentatív magyar mintán megfelelőnek bizonyult [11].

A Röviditett Beck Depresszió Kérdőin (BDI) magyar változata. A kilenc tételből álló, négyfokú, Likert-típusú skálán az egyáltalán nem jellemző (1) és a teljesen jellemző (4) végpontok között értékelendő kérdőív a depreszsziós tünetek súlyosságának közösségi felmérésekben alkalmazható, megbízható szűrőeszköze. A magasabb pontszám súlyosabb tüneteket jelez. A kérdőív belső megbízhatósága reprezentatív magyar mintán megfelelönek bizonyult [12].

A CES-D Depresszió Szürö Kérdöiv (Center for Epidemiologic Studies Depression Scale) 20 tételes, önjellemzéses, a depresszió mértékét elsősorban a normálpopulációban mérni hivatott, ugyanakkor a klinikai szintú problémát is elkülöníteni képes eszköz. Négyfokú skálán - „ritkán vagy soha” (0) és a „nagyon gyakran vagy mindig” (3) végpontok között - jelzi, hogy az egyes állítások mennyire igazak a válaszadóra nézve az elmúlt hétre vonatkozóan. Az alkalmazott kérdőívek közül ez az egyetlen olyan eszköz, amely aktuális állapotot, s nem vonás jellegú dimenziót mér [13].

A WHO Jóllét Kérdối (WBI-5) magyar változata. Az öttételes kérdőív a személyek általános közérzetét (például jókedv, nyugalom, ellazultság) méri fel a megelőző 
két hétre vonatkozóan. A tételek négyfokú, Likert-típusú skálán értékelendők az egyáltalán nem jellemző (0) és a nagyon jellemző (3) végpontok között. A skálán elért magasabb pontszám kedvezőbb pszichológiai jóllétet jelez. A skála belső megbízhatósága reprezentatív magyar mintán megfelelőnek bizonyult $[14,15]$.

\section{A skála magyar változatának kifejlesztése}

Miután a szerzőktől engedélyt kaptunk a skálák használatára, az eredeti, 30 tételes változatot három független fordító magyarra fordította, majd a kutatócsoport által közösen kialakított verziót egy angol fordító visszafordította angolra. Az eredetivel így összevetett fordításból alakítottuk ki a magyar változatot, amelyet 39 egyetemi hallgató tesztelt nyelvileg, a tartalom tekintetében és a kitöltés nehézsége szempontjából. A kitöltés tapasztalatai alapján megtörtént a magyar változat véglegesítése, és ezt használtuk a továbbiakban.

\section{A statisztikai adatfeldolgozás lépései}

Az elemzések elkészítéséhez IBM SPSS 23.0@ (International Business Machines Corporation, Armonk, NY, Amerikai Egyesült Államok) programcsomagot használtunk.

A mérőeszköz faktorstruktúrájának feltárásához faktoranalízist (fókomponens-elemzés, Varimax rotáció) végeztünk, melynek alapján feltártuk a 30 tételes, szakmai életminőségét mérő skála belső struktúráját. Ennek alapján készítettük el végül azt a 4 skálát, amely megfelelő Cronbach-alfa-értékekkel rendelkezett a további vizsgálatokhoz.

A faktorelemzéssel feltárt, majd megalkotott kérdőív alskáláinak megbízhatóságát a tételek belső konzisztenciáját mutató Cronbach-alfa-együttható kiszámításával vizsgáltuk.

Az alskálák külső validitásának ellenőrzése során már bemért, standardizált többi kérdőív skáláival való összehasonlításhoz, a Pearson-féle korrelációs együtthatók értelmezéséhez Cohen meghatározását vettük alapul: 0,3 alatt gyenge, 0,3-0,7 közepes erôsségű, 0,7 felett erős.

A megfelelő külső, illetve belső stabilitással bíró skálák esetében ismertetjük az általunk felvett mintán elért átlagos pontszámokat, valamint szóródási mértéket (szórás).

A ProQOL kérdőív alskálái külső validitásának ellenőrzése során a korábban lezajlott magyarországi életminőség-kutatásokban már bemért, standardizált kérdőíveket - Hungarostudy 2002, 2006, 2013 - használtuk annak érdekében, hogy később az adatok a nem egészségügyben dolgozók és az egészségügy más területein dolgozók adataival is összehasonlíthatók legyenek [1618].

\section{Eredmények}

\section{A minta ismertetése}

Az adatgyưjtés során 188 fơtől kaptunk vissza értékelhető kérdőíveket. A nők $(\mathrm{n}=162)$ és a férfiak $(\mathrm{n}=26)$ megoszlási aránya $86,2 \%$ : 13,8\% volt (tehát jellemző a nők felülreprezentáltsága, mint a segítő szakmákban általában).

A résztvevők munkaköri megoszlása szerint a legtöbben (94 fó) ápolóként, további 31 fő orvosként dolgozik. A további munkakörökről (például pszichológus, gyógytornász, lelkész, koordinátor stb.) 10 vagy annál alacsonyabb esetszámban érkeztek válaszok, tehát a minta kellően heterogénnek volt tekinthető. Munkahelyüket tekintve 58-an kórházban múködő hospice-szakápolásban vesznek részt, míg 94 fó otthoni hospice-ellátás keretében látja el feladatait.

Iskolai végzettség tekintetében 81 fó érettségizett, további 96 diplomás, 11 fó érettségi nélküli.

A résztvevők átlagéletkora 46,56 év volt $(S D=10,8$ év, terjedelem: 55 év, minimum 23 év, maximum 78 év).

\section{A kérdöin pszichometriai mutatóinak ismertetése}

A faktorelemzés során főkomponens-elemzést alkalmaztunk VARIMAX rotáció mellett. A KMO-érték megfelelően magasnak bizonyult, a Bartlett-teszt szignifikáns eredményt adott $\left(\mathrm{KMO}=0,829, \mathrm{khi}^{2}[435]=1856,363\right.$, $\mathrm{SIG}=0,0000)$. Ennek értelmében tehát megfelelő volt az adatstruktúra látens változók azonosítására. Esetünkben 7 különböző faktort alkottak az adatok.

A kommunalitása minden változónak meghaladta a 0,25-ös elvárható, minimális értéket, tehát változót nem kellett szelektálni a modellből (a legalacsonyabb kommunalitás 0,45 volt).

A 7 faktor együttes magyarázó ereje 60,318\% volt. Az első két faktor (rotáció után) 12,94\%-ot, illetve 12,47\%ot magyarázott. A további faktorok rendre $9 \%, 7,9 \%$,

1. táblázat |A ProQOL-alskálák alapstatisztikái

\begin{tabular}{lccc}
\hline & $\begin{array}{c}\text { A válaszadók } \\
\text { száma }\end{array}$ & Átlag & Szórás \\
\hline $\begin{array}{l}\text { ProQOL, 1: Munkából fakadó } \\
\text { érzelmi túlterheltség }\end{array}$ & 176 & 18,81 & 5,18 \\
\hline $\begin{array}{l}\text { ProQOL, 2: Munkával való } \\
\text { elégedettség }\end{array}$ & 175 & 39,84 & 5,34 \\
\hline $\begin{array}{l}\text { ProQOL, 3: Együttérzésből } \\
\text { fakadó elégedettség }\end{array}$ & 175 & 20,90 & 2,42 \\
\hline $\begin{array}{l}\text { ProQOL, 4: Másodlagos } \\
\text { traumatizáltság }\end{array}$ & 184 & 5,55 & 2,01 \\
\hline
\end{tabular}

ProQOL = a szakmai élet minőségét mérő skála 
$7,14 \%, 6,3 \%$ és 4,5\%-os magyarázó eróvel bírtak. Azonban voltak olyan tételek, amelyek a 7 faktor esetében két faktoron is elhelyezkedtek. Így ezeket a tételeket - egyszerüsítendő a faktorstruktúrát - átsoroltuk, illetve egyértelmúsítettük, hogy melyik faktorhoz tartozzanak (legalább 50\%-kal nagyobb súllyal szerepelt az adott faktoron, mint a másikon).
Az így keletkezett új faktorokat már skálaként kezeltük, és a táblázatok első sorában az elnevezés mellett feltüntetjük a Cronbach-alfa-értékeket is.

A kapott, populációs értékek az 1. táblázatban találhatók, a 2. táblázat a faktorelemzés alapján kialakított 5 új alskála kérdéseit, valamint megbízhatósági mutatóit tartalmazza.

2. táblázat |A faktorelemzés alapján kialakított 5 új alskála kérdései, valamint megbízhatósági mutatói
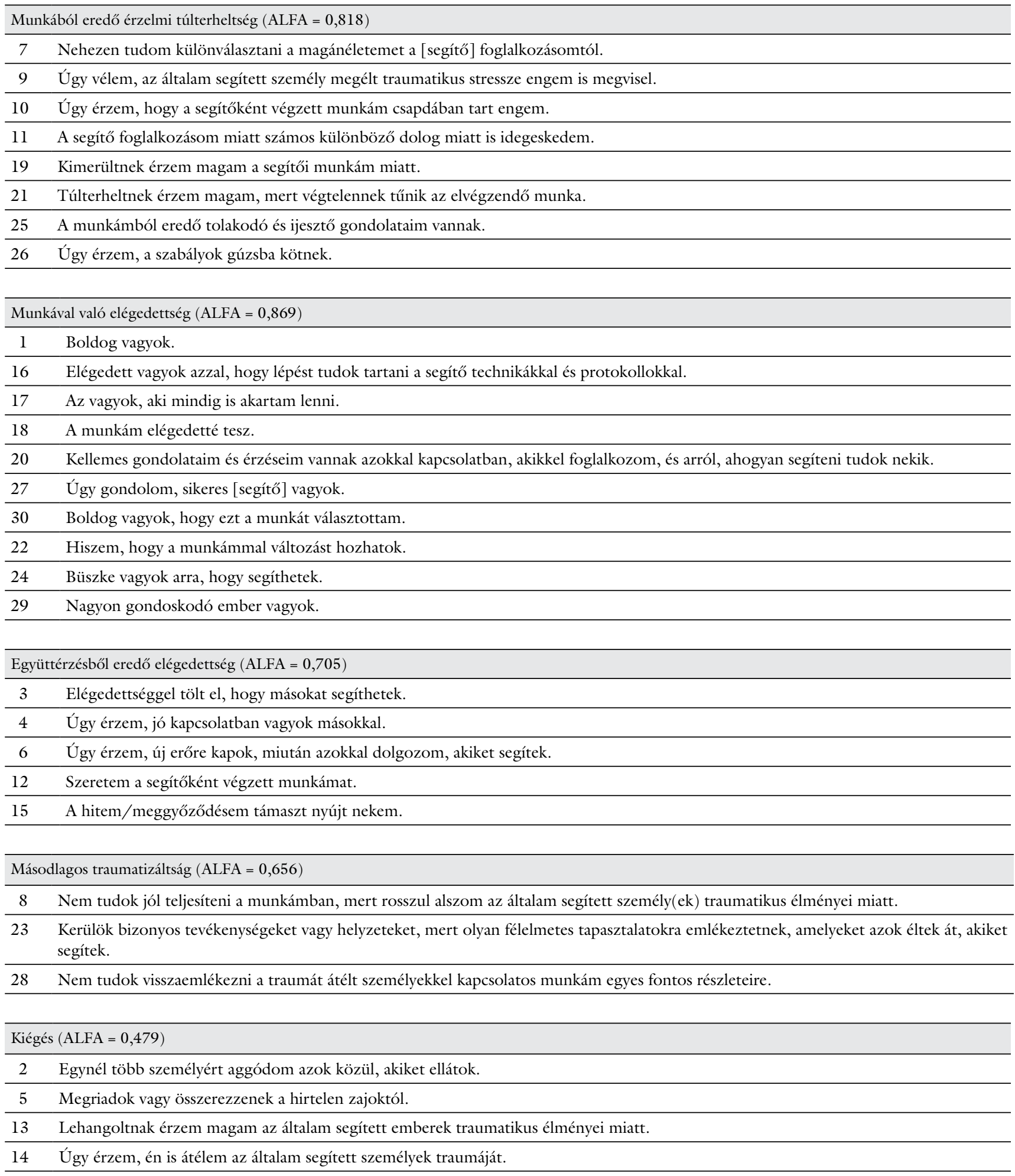


\section{A külsö skálák validitásának vizsgálata}

A skálák külső validitását különböző, a Hungarostudyvizsgálatok során bemért, standardizált kérdőívek skáláinak vizsgálatával, azokkal való együttjárással teszteltük, ellenőriztük. Miután a kiégés skála viselkedését nem találtuk megfelelőnek, így csak az első négy skála validitását ellenőriztük.

A másodlagos traumatizáltság és a munkából eredő érzelmi túlterheltség esetében az alábbi összefüggéseket találtuk:

- együttjárást mutatott a vitális kimerültséggel (VKK) és

a depresszióval (BDI, CES-D), mégpedig pozitív együttjárás mellett, tehát minél magasabb a kitöltőnek a másodlagos traumatizáltságot és a munkából eredő érzelmi túlterheltséget jelző értéke, annál magasabb a vitális kimerültség értéke is;

- együttjárást mutatott, mégpedig negatív együttjárás mellett az általános jólléttel (WHO WBI-5), vagyis minél magasabb a kitöltőnek a másodlagos traumatizáltságot és a munkából eredő érzelmi túlterheltséget jelző értéke, annál alacsonyabb az általános jóllét értéke.

A munkával való elégedettség és az együttérzésből eredő elégedettség esetében az alábbi összefüggéseket találtuk:

- együttjárást mutatott, mégpedig negatív együttjárás mellett a vitális kimerültséggel (VKK), a depresszióra utaló tünetekkel (BDI, CES-D), vagyis minél magasabb a kitöltőnek a munkával való, az együttérzésből eredő elégedettsége, várhatóan annál alacsonyabb a vitális kimerültség és a depresszió értéke is.

- együttjárást mutatott, mégpedig pozitív együttjárás mellett az általános jólléttel (WHO WBI-5), vagyis minél magasabb a munkával való és az együttérzésből eredő elégedettség, várhatóan annál magasabb a kitöltők általános jólléte.

A vizsgálat kimutatta, hogy a 3. táblázatban feltüntetett „r”-értékek mellett a feltételezésünk igaz volt.

\section{Megbeszélés}

A kérdőív statisztikai vizsgálatai során a faktorelemzés az izraeli, illetve a spanyol mintához képest eltérést mutatott. A hasonló munkakörben dolgozók válaszainak struktúrája mindkét korábbi vizsgálatban mindösszesen 3 faktorként rajzolódott ki. Ezért exploratív faktorelemzéssel megalkottuk azokat a skálákat, amelyek segítségével a saját kérdőívünk eredményei kiértékelhetővé váltak $[1,19]$.

A „Munkából eredő érzelmi túlterheltség” alskála elnevezését az támasztja alá, hogy a tételek leginkább a munkára mint segítő foglalkozásra és az abból eredő, elsősorban lelki megterhelődésre vonatkoznak. Várhatóan azoknál a kitöltőknél kapunk magasabb értékeket, akik túlterheltebbek, több munkahelyen és/vagy magasabb óraszámban dolgoznak [2, 20].

A „Munkával való elégedettség” alskálán a tételek az elégedettségre, ezen belül is elsősorban a segítő foglalkozásból eredő elégedettségre vonatkoznak. Várhatóan azoknál a válaszadóknál lesz magasabb, akik rugalmasságuk, szívósságuk, magasabb koherenciaérzékük által a segítő foglalkozásból eredő nehézségekkel, változásokkal való adekvát megküzdésen keresztül általános és munkából fakadó elégedettséget tapasztalnak [2, 2123]. Ebben a skálában 3 fordított tételt találunk: 1, 17,

3. táblázat |A ProQOL-alskálák Pearson-féle korrelációs együtthatóinak értékei a további kérdőívek skáláival

\begin{tabular}{|c|c|c|c|c|c|}
\hline & & $\begin{array}{c}\text { ProQOL, 4: } \\
\text { Másodlagos } \\
\text { traumatizáltság }\end{array}$ & $\begin{array}{c}\text { ProQOL, 3: } \\
\text { Együttérzésből } \\
\text { fakadó elégedettség }\end{array}$ & $\begin{array}{l}\text { ProQOL, 2: } \\
\text { Munkával való } \\
\text { elégedettség }\end{array}$ & $\begin{array}{c}\text { ProQOL, l: } \\
\text { Munkából fakadó } \\
\text { érzelmi túlterheltség }\end{array}$ \\
\hline \multirow{3}{*}{$\begin{array}{l}\text { VKK, } \\
\text { összesített }\end{array}$} & Pearson-féle korrelációs együttható & $0,316^{* *}$ & $-0,162^{*}$ & $-0,341^{* *}$ & $0,553^{* *}$ \\
\hline & p-érték & 0,000 & 0,033 & 0,000 & 0,000 \\
\hline & A válaszadók száma & 183 & 174 & 175 & 176 \\
\hline \multirow{3}{*}{$\begin{array}{l}\text { BDI, } \\
\text { összesített }\end{array}$} & Pearson-féle korrelációs együttható & $0,515^{* *}$ & $-0,359^{* *}$ & $-0,497^{* *}$ & $0,600^{* *}$ \\
\hline & p-érték & 0,000 & 0,000 & 0,000 & 0,000 \\
\hline & A válaszadók száma & 180 & 172 & 171 & 172 \\
\hline \multirow{3}{*}{$\begin{array}{l}\text { WHO WBI-5, } \\
\text { összesített }\end{array}$} & Pearson-féle korrelációs együttható & $-0,302^{* *}$ & $0,286^{* *}$ & $0,446^{* *}$ & $-0,376^{* *}$ \\
\hline & p-érték & 0,000 & 0,000 & 0,000 & 0,000 \\
\hline & A válaszadók száma & 181 & 172 & 172 & 173 \\
\hline \multirow{3}{*}{$\begin{array}{l}\text { CES-D, } \\
\text { összesített }\end{array}$} & Pearson-féle korrelációs együttható & $0,572^{* *}$ & $-0,334^{* *}$ & $-0,521^{* *}$ & $0,583^{* *}$ \\
\hline & p-érték & 0,000 & 0,001 & 0,000 & 0,000 \\
\hline & A válaszadók száma & 98 & 95 & 100 & 99 \\
\hline
\end{tabular}

BDI = Rövidített Beck Depresszió Kérdőív; CES-D = Depresszió szűrő kérdőív; ProQOL = a szakmai élet minőségét mérő skála; VKK = Rövidített Maastricht Vitális Kimerültség Kérdőív; WHO WBI-5 = WHO Jóllét Kérdőív rövidített (WB-5) változat ${ }^{*} 0,01<\mathrm{p}<0,05 ;{ }^{* *} \mathrm{p}<0,01$ 
29 - ezeket, bár a faktoron vannak, a modellben jó irányba kódolással vesszük figyelembe.

Az „Együttérzésből eredő elégedettség” alskála a beteg és a segítő foglalkozású személy kapcsolatából eredô pozitív hatásokat emeli ki, amely tételek tovább árnyalják a munkával való elégedettséget, és egy jelentős pozitív komponensére mutatnak rá [5]. Fontosnak tartjuk, hogy az együttérzésből eredő kifáradás mellett az elégedettség is megjelenik. A skálán várhatóan azok a segítő foglalkozásúak érnek el magasabb értékeket, akik munkájuk iránt elkötelezettebbek, a traumatizált betegekkel végzett munkájukat és céljaikat értékesnek élik meg [21]. Az érett segítő kapcsolat által nem az együttérzésből eredő kifáradást tapasztalják meg, hanem a pozitív hatásokat, ez pedig személyes növekedéshez vezethet. Ebben a skálában 2 fordított tételt találunk: 4, 15 - ezeket, bár a faktoron vannak, a modellben jó irányba kódolással veszszük figyelembe.

A „Másodlagos traumatizáltság” alskála tételei a segített személyek által átélt traumának a segítő személyre való hatásaira kérdeznek rá. Itt várhatóan magasabb pontszámot érnek el, akik veszélyeztetettebbek a segító szindrómára [24].

A „Kiégés” alskála a gondoskodás negatív hatásaira, tüneteire - lehangoltság, aggódás, ijedtség - utaló tételeket foglalja magában; várhatóan a magasabb pontszámot elérők segítő munkájukból eredően mind fizikálisan, mind lelkileg túlterheltek, munkahelyi, munkatársi támogatottságuk alacsony, és a megelőzés lehetőségeiben tájékozatlanok [25].

A kiégés esetében a Cronbach-alfa-érték elmarad az elvárható 0,7-es, minimális szinttôl. Azokban az esetekben, amikor a megbízhatósági mutató az adott felhasználási körben eléri vagy meghaladja a minimális 0,7 -es értéket, az alskálát érdemes lehet használni - ebben a körben azonban nem volt megbízható, így elemzésre ezt az alskálát nem alkalmaztuk. Az alacsony érték oka részben az lehet, hogy ebben a kiégésfaktorban több, az eredeti kérdőívben a kiégéshez kapcsolható kérdést tettünk fel, azonban a kiégésnek igen változó területeit, aspektusait ragadja meg ez a skála ebben a formában.

A nemzetközi és a hazai kutatások azt támasztják alá, hogy az egészségügy más területein dolgozókkal való összehasonlítás során a hospice-ban dolgozók kevésbé kiégettek [26-28].

A hospice-dolgozók körében Magyarországon végzett kutatás azt találta, hogy a segítők vezető tünetei - testi fájdalom, fáradtság, alvásproblémák - inkább az együttérzésből eredő kifáradásra utalnak [2].

A megalkotott skálák belső konzisztenciája a Cronbach-alfa-értékek alapján elfogadható minőségű volt $(0,7$ feletti vagy azt jelentős mértékben megközelítő értékekkel). Az utolsó, kiégést mérő kérdések belső konzisztenciája alacsony volt. A nem megfelelő Cronbachalfa-érték $(0,479)$ miatt a kiégés alskála értékeit a továbbiakban nem vettük figyelembe. A szakmai élet minőségét mérő kérdőív elsősorban a munkából eredő érzelmi túlterheltség, az együttérzésből eredő kifáradás és elégedettség feltérképezésére szolgál; a kiégés vizsgálatakor javasoljuk más, elsősorban a kiégést mérő skálák és a ProQOL együttes használatát.

A külső validitást mérō, már standardizált skálák és a megalkotott saját mérőeszközünk skáláinak együttjárása a megfelelő erősségú és irányú volt, a szakirodalmi alapoknak megfelelően viselkedtek tehát. Így kérdoívünk mind a belső, mind a külső mutatók alapján megfelelő konzisztencia mellett, az általunk elvárt értékek szerint mérte az általunk vizsgálni kívánt jelenségeket.

\section{Következtetés}

A kérdőív magyar nyelvű validálását és a hazai hospicegyakorlatba való bevezetését azért tartjuk fontosnak, mert a kérdőív alkalmazása a kiégésnek és az együttérzésből eredő fáradtságnak mint a kiégést megelőző állapotnak az együttes monitorozásával árnyaltabbá teheti a súlyos betegekkel foglalkozó segítók testi és lelki panaszainak, tüneteinek feltérképezését. Emellett ráirányíthatja a figyelmet a fizikai és emocionális megterhelésből eredő veszélyeztetettségükre is. A segítő foglalkozásúak az együttérzésből eredő kifáradás tüneteit alulértékelik, figyelmen kívül hagyják, tovább folytatják munkájukat, ami a munkavégzés hatékonyságának csökkenéséhez és súlyosabb állapot kialakulásához vezethet. A kérdőív sikeres bevezetése hozzájárulhat ahhoz a szemléletváltáshoz is, hogy a jövőben nagyobb hangsúlyt fektessünk az együttérzésből és a munkavégzésből eredő elégedettségre, az ezt erősítő képzési és intervenciós módszerek kidolgozására és alkalmazására, amelyek hosszú távon hozzájárulhatnak a munkatársak pályán maradásához.

Anyagi támogatás: A közlemény megírása anyagi támogatásban nem részesült.

Szerzői munkamegosztás: K. A.: A probléma felvetése, a magyar kérdőív kidolgozása, az eredmények értékelése, irodalomkutatás, a tanulmány megírása. T. Sz.: A statisztikai adatok elemzése, az eredmények értékelése, a tanulmány megírása. R. B.: Aktív részvétel a magyar kérdő́iv kidolgozásában, az adatok kezelésében. Z. Á.: Aktív részvétel a magyar kérdőív kidolgozásában. H. K.: Aktív részvétel a magyar kérdő́ív kidolgozásában, szakértôi részvétel az eredmények értelmezésében és a tanulmány végleges formájának kialakításában.

Érdekeltségek: A szerzőknek nincsenek érdekeltségeik.

\section{Köszönetnyilvánítás}

Köszönetet mondunk a magyar fordítás kidolgozásában részt vevő Raduch Csilla, Zörgö Szilvia és Zsák Éva, valamint a kutatástervezésben értékes javaslataival segítő $d r$. Czeglédi Edit kollégáknak. 
Amikor ön másokat segít, akkor az érintettek életével közvetlen kapcsolatba kerül. Ahogy azt már észrevehette, az ön által segített, gondozott személyekkel való együttérzése egyszerre gyakorolhat önre pozitív és negatív hatást. Az itt található kérdések az ön élményeire vonatkoznak, pozitívakra és negatívakra egyaránt. Gondoljon át minden egyes kérdést, önről és munkahelyi helyzetéről. Válassza ki azt a számot, amelyik a lehető legjobban mutatja, milyen gyakran élte át az egyes felsorolt élményeket az elmúlt 30 napban.

\begin{tabular}{|c|c|c|c|c|c|c|}
\hline & & Soha & Ritkán & Néha & Gyakran & $\begin{array}{l}\text { Nagyon } \\
\text { gyakran }\end{array}$ \\
\hline 1 & Boldog vagyok. & 1 & 2 & 3 & 4 & 5 \\
\hline 2 & Egynél több személyért aggódom azok közül, akiket ellátok. & 1 & 2 & 3 & 4 & 5 \\
\hline 3 & Elégedettséggel tölt el, hogy másokat segíthetek. & 1 & 2 & 3 & 4 & 5 \\
\hline 4 & Úgy érzem, jó kapcsolatban vagyok másokkal. & 1 & 2 & 3 & 4 & 5 \\
\hline 5 & Megriadok vagy összerezzenek a hirtelen zajoktól. & 1 & 2 & 3 & 4 & 5 \\
\hline 6 & $\begin{array}{l}\text { Úgy érzem, új erőre kapok, miután azokkal dolgozom, akiket } \\
\text { segítek. }\end{array}$ & 1 & 2 & 3 & 4 & 5 \\
\hline 7 & $\begin{array}{l}\text { Nehezen tudom különválasztani a magánéletemet a [segítő] } \\
\text { foglalkozásomtól. }\end{array}$ & 1 & 2 & 3 & 4 & 5 \\
\hline 8 & $\begin{array}{l}\text { Nem tudok jól teljesíteni a munkámban, mert rosszul alszom az } \\
\text { általam segített személy(ek) traumatikus élményei miatt. }\end{array}$ & 1 & 2 & 3 & 4 & 5 \\
\hline 9 & $\begin{array}{l}\text { Úgy vélem, az általam segített személy megélt traumatikus } \\
\text { stressze engem is megvisel. }\end{array}$ & 1 & 2 & 3 & 4 & 5 \\
\hline 10 & $\begin{array}{l}\text { Úgy érzem, hogy a segítőként végzett munkám csapdában tart } \\
\text { engem. }\end{array}$ & 1 & 2 & 3 & 4 & 5 \\
\hline 11 & $\begin{array}{l}\text { A segítő foglalkozásom miatt számos különböző dolog miatt is } \\
\text { idegeskedem. }\end{array}$ & 1 & 2 & 3 & 4 & 5 \\
\hline 12 & Szeretem a segítóként végzett munkámat. & 1 & 2 & 3 & 4 & 5 \\
\hline 13 & $\begin{array}{l}\text { Lehangoltnak érzem magam az általam segített emberek } \\
\text { traumatikus élményei miatt. }\end{array}$ & 1 & 2 & 3 & 4 & 5 \\
\hline 14 & Úgy érzem, én is átélem az általam segített személyek traumáját. & 1 & 2 & 3 & 4 & 5 \\
\hline 15 & A hitem/meggyőződésem támaszt nyújt nekem. & 1 & 2 & 3 & 4 & 5 \\
\hline 16 & $\begin{array}{l}\text { Elégedett vagyok azzal, hogy lépést tudok tartani a segítő } \\
\text { technikákkal és protokollokkal. }\end{array}$ & 1 & 2 & 3 & 4 & 5 \\
\hline 17 & Az vagyok, aki mindig is akartam lenni. & 1 & 2 & 3 & 4 & 5 \\
\hline 18 & A munkám elégedetté tesz. & 1 & 2 & 3 & 4 & 5 \\
\hline 19 & Kimerültnek érzem magam a segítői munkám miatt. & 1 & 2 & 3 & 4 & 5 \\
\hline 20 & $\begin{array}{l}\text { Kellemes gondolataim és érzéseim vannak azokkal kapcsolatban, } \\
\text { akikkel foglalkozom, és azzal, ahogyan segíteni tudok nekik. }\end{array}$ & 1 & 2 & 3 & 4 & 5 \\
\hline 21 & $\begin{array}{l}\text { Túlterheltnek érzem magam, mert végtelennek tünik az elvégzen- } \\
\text { dő munka. }\end{array}$ & 1 & 2 & 3 & 4 & 5 \\
\hline 22 & Hiszem, hogy a munkámmal változást hozhatok. & 1 & 2 & 3 & 4 & 5 \\
\hline 23 & $\begin{array}{l}\text { Kerülök bizonyos tevékenységeket vagy helyzeteket, mert olyan } \\
\text { félelmetes tapasztalatokra emlékeztetnek, amelyeket azok éltek át, } \\
\text { akiket segítek. }\end{array}$ & 1 & 2 & 3 & 4 & 5 \\
\hline 24 & Büszke vagyok arra, hogy segíthetek. & 1 & 2 & 3 & 4 & 5 \\
\hline 25 & A munkámból eredő tolakodó és ijesztő gondolataim vannak. & 1 & 2 & 3 & 4 & 5 \\
\hline 26 & Úgy érzem, a szabályok gúzsba kötnek. & 1 & 2 & 3 & 4 & 5 \\
\hline 27 & Úgy gondolom, sikeres [segítő] vagyok. & 1 & 2 & 3 & 4 & 5 \\
\hline 28 & $\begin{array}{l}\text { Nem tudok visszaemlékezni a traumát átélt személyekkel } \\
\text { kapcsolatos munkám egyes fontos részleteire. }\end{array}$ & 1 & 2 & 3 & 4 & 5 \\
\hline 29 & Nagyon gondoskodó ember vagyok. & 1 & 2 & 3 & 4 & 5 \\
\hline 30 & Boldog vagyok, hogy ezt a munkát választottam. & 1 & 2 & 3 & 4 & 5 \\
\hline
\end{tabular}




\section{Irodalom}

[1] Samson T, Iecovich E, Shvartzman P. Psychometric characteristics of the Hebrew version of the Professional Quality-of-Life Scale. J Pain Symptom Manage. 2016; 52: 575-581.el.

[2] Révay E, Kegye A, Zana Á, et al. The everyday life of survivors. The quality of life of hospice workers. [A túlélők mindennapjai. A hospice-ellátásban dolgozók életminősége.] Orv Hetil. 2016; 157: 1000-1006. [Hungarian]

[3] Kegye A, Zana A, Révay E, et al. The real cost of caring for seriously ill patients - compassion fatigue or satisfaction. [A súlyos betegek ellátásának igazi ára - az együttérzésből fakadó fáradtság vagy elégedettség.] Lege Artis Med. 2015; 25: 129-136. [Hungarian ]

[4] Kegye A, Zana Á, Hegedűs K. How does the suffering of cancer patients affect us? Reviewing the physical and mental wellbeing of hospice workers. Palliat Med Pract. 2016; 10: 174-184.

[5] Kearney MK, Weininger RB, Vachon ML, et al. Self-care of physicians caring for patients at the end of life. JAMA 2009; 301: $1155-1164$

[6] Stamm BH. (ed.) The concise ProQOL manual. The ProQOL. org, Pocatello, 2010. Available from: http://www.proqol.org/ uploads/ProQOL_Concise_2ndEd_12-2010.pdf

[7] Slocum-Gori S, Hemsworth D, Chan WW, et al. Understanding compassion satisfaction, compassion fatigue and burnout: A survey of the hospice palliative care workforce. Palliat Med. 2011; 27: $172-178$

[8] Melvin CS. Professional compassion fatigue: what is the true cost of nurses caring for the dying? Int J Palliat Nurs. 2012; 18: 606611

[9] Busa Cs, Zeller J, Csikós Á. Who should decide at the end of life? International practice of advance care planning and possibilities for adaptation in Hungary. [Ki döntsön az élet végén? Az ellátás előzetes tervezésének nemzetközi gyakorlata és hazai lehetőségei.] Orv Hetil. 2018; 159: 131-140. [Hungarian]

[10] Hegedûs K, Lukács M, Schaffer J, et al. Situation, possibilities and difficulties of the hospice and palliative care in Hungary. [A hazai hospice- és palliatív ellátás helyzete, lehetőségei, nehézségei.] Orv Hetil. 2014; 155: 1504-1509. [Hungarian]

[11] Kopp MS, Falger PR, Appels A, et al. Depressive symptomatology and vital exhaustion are differentially related to behavioral risk factors for coronary artery disease. Psychosom Med. 1998; 60: 752-758

[12] Rózsa S, Szádóczky E, Füredi J. Characteristics of the Short Version of the Beck Depression Inventory in the Hungarian sample. [A Beck Depresszió Kérdőív rövidített változatának jellemzői a hazai mintán.] Psychiatr Hung. 2001; 16: 379-397. [Hungarian]

[13] Radloff LS. The CES-D Scale: A self-report depression scale for research in the general population. Appl Psychol Meas. 1977; 1: 385-401

[14] Susánszky É, Konkolÿ Thege B, Stauder A, et al. Validation of the short (5-item) version of the WHO Well-Being Scale based on a Hungarian representative health survey (Hungarostudy 2002). [A WHO Jól-lét kérdő́iv rövidített (WBI-5) magyar változatának validálása a Hungarostudy 2002 országos lakossági egészségfelmérés alapján.] Mentálhig Pszichoszom. 2006; 7: 247-255. [Hungarian]

[15] Dinyáné Szabó M, Pusztai G. Use of the short (5-item) version of the WHO well-being questionnaire in first year students of Semmelweis University. [Az Egészségügyi Világszervezet öttéte- les jól-lét kérdőivének vizsgálata a Semmelweis Egyetem elsőéves hallgatóinak körében.] Orv Hetil. 2016; 157: 1762-1768.

[16] Kopp M, Kovács M. Appendix: Questionnaires used in the 2002 Hungarostudy survey. In: Kopp M, Kovács M. (eds.) Quality of life of the Hungarian population at the turn of the millenary. [Melléklet: A Hungarostudy 2002 felmérésben használt kérdőívek. In: Kopp M, Kovács M. (szerk.) A magyar népesség életminősége az ezredfordulón.] Semmelweis Kiadó, Budapest, 2006. [Hungarian]

[17] Kopp M, Rózsa S, Skrabski Á. Questionnaires used in the 2002 and 2006 follow-up Hungarostudy survey. In: Kopp M. (ed.) Hungarian state of mind, 2008. [A Hungarostudy 2002 és a Hungarostudy 2006 követéses vizsgálat kérdő́ivei. In: Kopp M. (szerk.) Magyar lelkiállapot, 2008.] Semmelweis Kiadó, Budapest, 2008. [Hungarian]

[18] Susánszky É, Székely A. The metodology of the Hungarosudy 2013 survey. In: Susánszky É, Szántó Zs. (eds.) Hungarian state of mind, 2013. [A Hungarostudy 2013 felmérés módszertana. In: Susánszky É, Szántó Zs. (szerk.) Magyar lelkiállapot, 2013.] Semmelweis Kiadó, Budapest, 2013. [Hungarian]

[19] Galiana L, Arena F, Oliver A, et al. Compassion satisfaction, compassion fatique, and burnout in Spain and Brazil: ProQOL validation and cross-cultural diagnosis. J Pain Symptom Manage. 2017; 53: 598-604.

[20] Csupor É, Kuna Á, Pintér JN, et al. Types of conflicts and conflict management among Hungarian healthcare workers. [Konfliktustípusok és konfliktuskezelés magyar egészségügyi dolgozók körében.] Orv Hetil. 2017; 158: 625-632.

[21] Ablett JR, Jones RS. Resilience and well-being in palliative care staff: A qualitative study of hospice nurses' experience of work. Psychooncology 2007; 16: 733-740.

[22] Tselebis A, Moulou A, Ilias I. Burnout versus depression and sense of coherence: study of Greek nursing staff. Nurs Health Sci. 2001; 3: 69-71.

[23] Koen MP, Van Eeden C, Wissing MP. The prevalence of resilience in a group of professional nurses. Health SA Gesondheid 2011; 16: 1-11.

[24] Fekete S. The risks of helper professions - the Helfer syndrome and the Burnout phenomenon. [Segítő foglalkozások kockázatai - Helfer-szindróma és Burnout-jelenség.] Psych Hung. 1991; 6: 17-29. [Hungarian]

[25] Kovács M, Kovács E, Hegedús K. Is emotional dissonance more prevalent in oncology care? Emotion work, burnout and coping. Psychooncology 2010; 19: 855-862.

[26] Kalicińska M, Chylińska J, Wilczek-Różyczka E. Professional burnout and social support in the workplace among hospice nurses and midwives in Poland. Int J Nurs Pract. 2012; 18: 595603.

[27] Ostacoli L, Cavallo M, Zuffranieri M, et al. Comparison of experienced burnout symptoms in specialist oncology nurses working in hospital oncology units or in hospices. Palliat Support Care 2010; 8: 427-432.

[28] Szabó N, Szabó G, Hegedûs K. Interdisciplinarity, workplace stress, holistic management. [Interdiszciplinaritás, munkahelyi stressz, holisztikus szemléletû́ ellátás.] Lege Artis Med. 2008; 18: 243-249. [Hungarian]

(Kegye Adrienn dr., Budapest, Nagyvárad tér 4. XX. emelet, 1089 e-mail: kegyeadrienne@gmail.com) 